\title{
God and Green: Investigating the Impact of Religiousness on Green Marketing
}

\begin{abstract}
As the population increases, more people are now aware of the impact of their consumption on the natural environment. Nonetheless, one important factor that is often neglected is religiousness. Studies of the impact of religiousness on individual behavior have become increasingly important because the majority of the world population belongs to one of the major world religions. Thus, the purpose of this study is to investigate the impact of consumers' religiousness toward pro-environmental identity, attitudes toward environmental issues, and subjective norms about the environment. Subsequently, this study investigates the impact of these variables on purchase intention of green products. Using sampling from Indonesia $(n=649)$, which has the largest Muslim population; the results show significant differences between religions. In general, similar findings were identified in both samples of Muslim and Christian consumers, where intrinsic religiousness has a positive impact on proenvironmental identity, attitudes towards environmental issues, and subjective norms about the environment. The study also found that the three variables (pro-environmental identity, attitudes towards environmental issues, and subjective norms) are positive determinants of intention to purchase green products. Nevertheless, the role of extrinsic religiousness is different for the two samples. Extrinsic religiousness is negatively related to attitude towards environmental issues for Muslim consumers, where it has a positive influence on proenvironmental identity among Christian consumers. The results of this study have significant implications not only to managers but also religious leaders on how to encourage more positive attitudes toward the environment.
\end{abstract}

Keywords: religiousness; green marketing, pro-environmental identity; attitudes, subjective norms about the environment. 


\section{Introduction}

In the debates between climate change's believers and skeptics, religion has been considered to play a significant role (Kalamas et al. 2013; Martin and Bateman 2014; Minton, et al.

2015). Studies of the impact of religiousness on individual behavior have become increasingly important because the majority of the world population belongs to one of the major world religions (Engelland 2014). It was estimated that about 4.6 billion people out of 7.12 billion in the world said that religion is an important part of their daily life (Diener et al. 2011). A report suggests that Islam and Christianity are among the fastest growing faiths.

Muslims will reach 2.76 billion while Christianity will reach 2.92 billion in 2050 (CNN 2015; Pew Research Center 2015). As the population increases, more people are now aware of the impact of their consumption on the natural environment (Mostafa, 2007). As a consequence, the numbers of green consumers are increasing and they are willing to pay more for environmentally friendly products (Banerjee et al. 1995; Coddington 1993).

Studies on the impact of religiousness toward the environment have produced conflicting results. Smith and Leosrowith (2013) found that American evangelicals were less likely to believe that climate change is happening and less likely to express concern and worry, compared with the nonevangelicals. This is particularly concerning when more companies now devote their efforts toward improving the environment and sustainability.

Most studies have focused on the impact of religiousness on environmental attitudes and behaviors only in the context of the Judeo-Christian context (e.g., Martin and Bateman 2014; Schultz et al. 2000). One of the studies has indicated the positive impact of religiousness toward protecting the environment (Wolkomir et al. 1997). Nevertheless, there are still few studies exploring the impact of religion toward green marketing in the Muslim context or non-Judeo-Christian's context (Minton et al. 2015). In addition, little research investigates how religious affiliation could influence consumers' participation in sustainable 
behaviors (Engelland 2014; Minton et al. 2015; Minton and Kahle 2013). The importance of looking at a specific religious belief is that each religion has its own set of values, beliefs, and approaches toward a particular behavior (Allport and Ross 1967; Arli and Lasmono 2015; Zinnbauer et al. 1997). Thus, individuals living in the Muslim-dominated culture will differ significantly in their approach toward the environment compared with their counterparts living in a Christian-dominated culture (Aminzadeh 2013; Minton et al. 2015). Therefore, the current study focuses on the Indonesian context, the fourth most populated country with the largest number of Muslims in the world. Specifically, the purpose of the present study is to investigate the impact of people's religiousness toward pro-environmental identity, attitudes toward environmental issues, and subjective norms about the environment. This study then investigates the impact of these attitudes toward the intention to purchase green products. Subsequently, the study will explore similarities and differences between these religions. The results of this comparison will provide an indication of how much each religion influences one another.

\section{Literature Review and Hypothesis Development}

Theoretical framework

The current study applies the theory of religious values, which suggests that religion does not directly enforce obligations but usually moralistically offers certain values, beliefs, and practices that the believers can use in their day-to-day living (Hirschman et al. 2011; Worthington et al. 2003). Studies have indicated that there are two important components of religiousness — religious affiliation and religious commitment (Hirschman 1983; Melé 2006; Swimberghe et al. 2009; Wilkes et al. 1986; Worthington et al. 2003). The two components involve both cognitive and behavioral measures of religiousness (Hirschman 1983). A cognitive system in a religion is a "set of beliefs, values, expectations and behaviors that are 
shared by members of a group" (Esso and Dibb 2004, p. 686). Furthermore, the behavior is the consequence of those beliefs embedded in the mind of a religious follower (Swimberghe et al. 2009). This will influence their identity and attitudes toward a particular behavior (Melé 2009; Zinbauer et al. 1997).

Allport and Ross (1967) defined religious orientation as the extent to which a person lives out his or her religious beliefs. The degree to which an individual is committed to a particular belief is one of the most important cultural forces and a key influence in buyer behavior (Delener 1990; Esso and Dibb 2004). Allport and Ross (1967) suggested that religious motivations can be viewed in terms of intrinsic and extrinsic religiousness. The “extrinsically motivated person uses his religion, while intrinsically motivated person lives his religion" (Allport 1950, p. 449). An individual with strong intrinsic religiousness tends to live daily life according to her or his religion without expecting anything in return from their relationship with God. In contrast, an individual with strong extrinsic religiousness might be more influenced by social determinants and participate in religious activities to meet personal needs (e.g., source of comfort and peace) or for social goals (e.g., social support) (Allport 1950; Vitell et al. 2005). Through separating religiousness, Allport and Ross (1967) were able to explain discrepancies of findings in the area of religiousness. Studies have found differences between intrinsic and extrinsic religion to a variety of variables, such as coping styles (Pargament et al. 1988), ethics (Arli and Tjiptono, 2014), narcissism (Watson et al. 1987), altruism (Chau et al. 1990), fear of death (Cohen et at 2005) and a wide variety of prejudice (Whitley 2009).

In the marketing literature, studies have shown that religiousness greatly influences attitude, which subsequently affects purchasing behavior (Bailey and Sood 1993; Esso and Dibb 2004; Delener 1994; Hirchman 1981), such as choice of entertainment (Hirchman 1983), choice of political party (Will 1991; Kohut et al. 2000), and consumer ethical behavior 
(Vitell et al. 2005; Arli and Tjiptono 2014) and recently, Minton et al. (2015) found that religiousness moderates consumers' participation in sustainable behavior. In addition, each core religious belief may influence consumers' sustainable behavior differently (Eckberg and Blocker 1989; Minton et al. 2015; James 2004).

\section{Hypothesis Development}

The study proposes the impact of consumers' religiosity (i.e., intrinsic and extrinsic) on proenvironmental identity, attitudes toward environmental issues and subjective norms. Subsequently, the study will test the impact of these variables on consumers' intention to purchase green products. Figure 1 shows our proposed conceptual framework.

\section{Insert Figure 1 about Here}

\section{Pro-environmental identity}

Self-identity can be defined as the label used to describe oneself (Cook et al. 2002).

Consumers' beliefs on environmental issues have been linked to positive environmental behaviors (Gadenne et al. 2011; Tanner and Kast 2003). Self-identity often serves to differentiate oneself from others and to conform to the values, beliefs, and behaviors of the social groups (e.g., religion, political party) where they belong (Christensen et al. 2004; Whitmarsh and O’Neill 2010). Self-identity has been found to be a significant predictor of behavior pertaining to pro-environmental action (Fekadu and Kraft 2001; Sparks and Shepherd 1992; Sparks et al. 1995; Terry et al. 1999). One study found that consumers who identify themselves as green consumers are more likely to to consume organic vegetables (Whitmarsh and O'Neill 2010). Consumers with stronger pro-environmental beliefs or those who think of themselves as people who care about the environment were found to be more likely to engage in environmental-oriented purchasing behavior (Gadenne et al. 2011; 
Mainieri et al. 1997; Pickett-Bake and Ozaki 2008). For Islam and Christianity, the following hypotheses are being offered:

H1 ISLAM: Pro-environmental identity will be positively related to intention to purchase green products.

H1 Christianity: Pro-environmental identity will be positively related to intention to purchase green products.

\section{Attitudes toward environmental issues}

Decades of research on pro-environmental behaviors have revealed that psychographic characteristics (i.e., attitudes, values) are better predictors than standard demographic variables (Cleveland et al. 2005; Guagano 1995; Kalamas et al. 2014). A study has shown that attitudes toward the environment are an important determinant in buying organic food (Grunert 1993). Positive consumer attitude may translate into various behaviors, such as recycling and buying green products. Environmental attitude can be defined as "the collection of beliefs, affects, and behavioral intentions a person holds regarding environmentally-related activities or issues" (Schultz et al. 2004, p. 31). Most studies on environmental research, especially those explaining attitude formation in the adoption of green products and behaviors (e.g., Bamberg 2003; Fujii and Taniguchi 2006; Klockner 2013), have relied on Ajzen and Fishbein's (1980) Theory of Reasoned Action (TRA) and Ajzen's (1991) Theory of Planned Behavior (TPB). The theories suggest the process by which consumers' beliefs form attitudes toward certain behaviors and lead to their adoption (Ozaki and Sevastyanova 2011). Greater concern for environmental issues has driven consumers of all demographics to participate in environmental activities (Granzin and Olson 1991). Banerjee and McKeage (1994) found that consumers' perception about the severity of the environmental problem influenced his/her willingness to pay more for environmentally friendly products. In an early study, Webster (1975) found that socially conscious consumers had tried to consider the social impact of their buying behavior. Numerous follow up studies confirmed that environmental concern 
leads to ecologically responsible attitude and behavior (Mostafa 2007; Simmons and Widmar 1990). Hence, for Islam and Christianity, we propose:

H2 ISLAM: Attitudes toward environmental issues will be positively related to intention to purchase green products.

H2 Christianity: Attitudes toward environmental issues will be positively related to intention to purchase green products.

\section{Subjective norms about the environment}

Subjective norm refers to an individual's perceived social pressure to perform a certain behavior (Ajzen 1985; Sparks et al. 1992). Subjective norms about the environment plays an important role in green product purchases (Peattie 2010). Ozaki (2011) found that the strength of social and community can influence consumers to adopt a green electricity tariff. The intention to undertake a particular behavior is strongly affected by social norms (Bamberg 2003). Gadenne et al. (2011, p. 7686) argue that "presenting a positive image of oneself is very important and this encourages people to conform to the norms of the groups to which they want to belong." Numerous studies show that consumers are influenced by the actions and opinions of others (i.e., family, friends) who are important to them (Jager 2006; Pickett-Baker and Ozaki 2008; Sidiras and Koukios 2004). Subjective norms or perceived social pressure have been found to influence individuals' behavior related to intention to consume green products (Bamberg 2003; Kalafatis et al. 1999; Kim and Chung 2011). Hence, the following hypotheses are put forward:

H3 ISLAM: Subjective norms about the environment will be positively related to intention to purchase green products.

H3 CHRISTIAN: Subjective norms about the environment will be positively related to intention to purchase green products. 


\section{Religiousness - Islam}

In the context of environment and sustainability, Islamic law supports the preservation and protection of the environment (Bazzi 2013). One of the most popular Hadiths (i.e., the collected report of what the prophet Muhammad said) on the environment is 'the earth is green and beautiful and Allah has appointed you his stewards over it.' Moreover, the Caliph Abu Bakt (the father-in-law of Islamic prophet Muhammad) once said, "do not destroy palm trees, don't burn houses or fields of wheat, never cut down fruit trees, and kill cattle only when you need to eat it" (Schwarte 1992, p. 270).

In addition, cleanliness is an indispensable part of being faithful in Islam. Before praying, a Muslim needs to wash his/her face, hands, feet, and mouth with pure water three times. Merchant (1992 p. 124) argues that "Islam presents a brilliant set of information on ecological issues. In an Islamic perspective, man is God's vice regent on the earth. The Quran teaches that the universe, nature, and the environment are all signs of the Creator of the world. No religion has ever warned so forcefully against devastating the environment and animal life or prohibited the destruction of God's gifted natural wealth and resources as Islam has." In Islamic culture, humans are part of the larger scheme to bring a perfect equilibrium to things. Thus, they are entrusted to manage the earth as a steward of God. This concept is in contrast to the Judeo-Christian view of humans as the ones who dominate nature (Mostafa 2007; Schultz et al. 2004). This is an indication that, in Islam, human beings have been given the responsibility to preserve and maintain the natural environment (Zafar 2014). Thus, we propose the following hypotheses.

H4 ISLAM: Intrinsic religiousness will be positively related to pro-environmental identity.

H5 ISLAM: Intrinsic religiousness will be positively related to attitudes toward environmental issues.

H6 ISLAM: Intrinsic religiousness will be positively related to subjective norms. 
In the context of extrinsic religiousness, Vitell et al. (2005) suggest that individuals with a high degree of extrinsic religiousness might not necessarily be as committed to his/her religion as they might appear to be, thus, might not be as caring for the environment compared with individuals with high intrinsic religiousness. Donahue (1985) found that extrinsic religiousness was correlated less with religious commitment. Thus, in the context of Islam, we will examine the following hypotheses:

H7 ISLAM: Extrinsic religiousness will be negatively related to pro-environmental identity.

H8 ISLAM: Extrinsic religiousness will be negatively related to attitudes toward environmental issues.

H9 ISLAM: Extrinsic religiousness will be negatively related to subjective norms.

\section{Religiousness - Christianity}

Concern for the environment is one of the most controversial issues facing Christians today (Merrit et al. 2010; Schreck 2004). Studies on the impact of religiousness (Christian context) produced conflicting results. The first group of studies showed that high religiousness or (i.e., intrinsic religiosity) is correlated with a lower level of environmental concern (Biel and Nilsson 2005; Eckberg and Blocker 1996; Guth et al. 1995; Sherkat and Ellison 2007). American evangelicals are less likely to believe that global warming is happening (Smith and Leiserowitz 2013) and less likely to engage in environmentally friendly behaviors than the nonreligious consumers (Engelland 2014; Martin and Bateman 2014) and less concerned about environmental impacts on plants and animals (Schultz et al. 2000).

In contrast, other studies found that individuals who attend church (i.e. frequencies of attendance) are more likely to engage in environmentally friendly behavior (Kanagy and Willits 1993; Wolkomir et al. 1997; Woodrum and Wolkomir 1997). Tucker (2003) argues that religion has the unique ability to construct moral and ethical frameworks that can 
encourage human beings to protect the earth, a place created by God. Many have argued that Christians have a moral responsibility to protect God's creation (Kearns 1997; Robinson 2010). In many of his messages, Pope Benedict XVI urged Catholics to preserve the environment. Among the messages are: "We are all responsible for the protection and care of the environment. This responsibility knows no boundaries", "The relationship between individuals or communities and the environment ultimately stems from their relationship with God", and "... the Church considers matters concerning the environment and its protection intimately linked to the theme of integral human development." (The Interfaith Center for Sustainable Development 2015). Recently, Pope Francis’ encyclical letter Laudato Si' calls for an 'ecological conversion'. The Pope suggested that Christians have misinterpreted scripture and "must forcefully reject the notion that our being created in God's image and given dominion over the earth justifies absolute domination over other creatures" (Pope Francis 2015, p. 49). He further explains that the Bible tells us to "till and keep" the garden of the world, where "tilling" refers to "cultivating, ploughing or working", whereas "keeping" means "caring, protecting, overseeing and preserving" (p. 49). This is a strong message to accept responsibility for protecting the environment. In general, recent studies indicated that highly religious consumers (i.e. intrinsic religiosity), in the context of Western religions, are more likely to participate in sustainable behaviors than less religious consumers (Djupe and Gwiasda 2010; Minton et al. 2015). Moreover, studies in the context of developing countries indicated that religion influences ethical behaviors (Arli and Tjiptono 2014; Casidy et al 2016). Hence, we propose the following hypotheses for Christianity:

H4 CHRISTIANITY: Intrinsic religiousness will be positively related to proenvironmental identity.

H5 CHRISTIANITY: Intrinsic religiousness will be positively related to attitudes toward environmental issues.

H6 ChRISTIANITY: Intrinsic religiousness will be positively related to subjective norms. 
Because studies show conflicting results between religious and nonreligious people in their attitude toward the environment, individuals with a high degree of extrinsic religiousness will be different in their perception and attitude toward the environment compared with individuals with high intrinsic religiousness. Thus, we propose the following hypotheses:

H7 CHRISTIANITY: Extrinsic religiousness will be negatively related to proenvironmental identity.

H8 Christianity: Extrinsic religiousness will be negatively related to attitudes toward environmental issues.

H9 ChRistianity: Extrinsic religiousness will be negatively related to subjective norms.

\section{Methodology}

Data collection

As a religious society where about $98 \%$ of individuals participating in the Gallup World Poll from 2005 to 2009 reported that religion was an important part of their daily life (Diener et al. 2011), Indonesia is an ideal context to investigate the impact of religiousness on consumer behavior. Indonesia is a country of cultural diversity and home to the largest Muslim population $(86.1 \%)$ in the world, followed by $8.7 \%$ Protestant/Catholic, $3 \%$ Hindu, and $1.8 \%$ others (World Population Review 2014). Indonesia is the fourth most populous nation in the world with approximately 253 million people and it is the largest country in Southeast Asia (World Population Review 2014). Officially, each citizen is required to state his/her religion on their identity cards.

Data were derived using a convenience sampling of student and nonstudent samples. Student samples were approached in classrooms and public spaces (e.g., canteens and students' lounge rooms) of three large universities (i.e., one public and two major private 
universities) in Yogyakarta, Indonesia. Nonstudent samples were interviewed in two shopping malls and several housing areas in the city. A total of 700 questionnaires were distributed; 684 returned; but only 649 were usable, thereby offering an overall response rate of $93 \%$. Male and female respondents were $45.8 \%$ and $54.2 \%$, respectively. A majority of the respondents was single $(61.9 \%)$, followed by married $(34.4 \%)$ with $27.9 \%$ between the ages of 18 and 20 years and $37 \%$ aged above 26 years old. In terms of religions, about $36.2 \%$ of the respondents were Muslims and $63.8 \%$ of them were Catholics/Protestants. Table 1 summarizes the demographic profiles of respondents. The religion profile of the sample differs from the actual populations, 36.2\% versus $86.1 \%$ (actual Muslims Indonesia). Nonetheless, it is still an indication of the majority of sample. As the purpose of this study is the compare and contrast the impact of religion on consumers' identity, attitudes and their subjective norms. The proportion of the sample can be deemed acceptable.

\section{Insert Table 1 about Here}

\section{Measures}

All scales were Likert-type scales adapted from established multi-item scales. The intrinsic/extrinsic religiousness scales were adapted from Allport and Ross (1967). Allport's Religious Orientation Scale (ROS) is one of the most frequently used measures to determine the degree to which a person internalizes and practices religious beliefs and values (Donahue 1985; Vitell et al. 2009). The intrinsic dimension contains eight items, exemplified by items such as "I try hard to live all my life according to my religious beliefs." The extrinsic dimension includes three items, such as "I go to religious services mostly to spend time with my friends." Pro-environmental identity was measured using an adapted scale from Cook with item from Cook et al. (2002) with items such as "I think of myself as someone who is very concerned about environmental issues." Attitudes toward environmental issues were measured using items from Bohlen et al. (1993). An example of such an item is "The 
environment is one of the most important issues facing society today." Subjective norms about the environment were measured using items adapted from Fishbein and Ajzen (1975). An example of such an item is "Most people who are important to me buy environmentally friendly household products.” Finally, purchase intention was evaluated by asking participants "In the next six weeks, how likely are you to purchase environmentally friendly household products?" It was rated on a scale ranging from 1 (not at all likely) to 5 (extremely likely). Tables 2 and 3 report correlations and mean values of the scales. Subsequently, Table 4 reports the scale items used in this study.

\section{Insert Tables 2-4 about Here}

Reliability and validity of the measures

Following procedures by Mathieu and Taylor (2006), we performed confirmatory factor analysis (CFA) for the model constructs. Using analysis of moment structures (AMOS), we conducted a CFA test to examine all measures simultaneously. The model fits the data adequately $(\mathrm{CFI}=0.908, \mathrm{IFI}=0.909, \mathrm{RMSEA}=0.041)$. The confirmatory $(\mathrm{CFI})$ and Incremental (IFI) fit indexes both were above the 0.90 cutoff (Hu and Bentler, 1999). We assessed the validity and reliability of the measures in multiple ways. To assess the convergent validity, we evaluated Cronbach's $\alpha$, average variance extracted (AVE), factor loadings, and composite reliability. For all constructs, the Cronbach $\alpha$ and factor loadings reached values above the required thresholds of 0.7 and 0.5 , respectively (Fornell and Larcker 1981). The AVEs for all constructs were greater than the 0.50 benchmark (Fornell and Larcker 1981; Hair et al. 2006). All CR values exceeded the threshold of 0.60, providing support for the reliability of the scales exceeding the cutoff of 0.60 for satisfactory internal reliability. Overall, these results support the convergent validity of the scales (Andersen and Gerbing 1988). As shown in Table 4, all constructs met the criterion for discriminant validity. 


\section{Hypothesis Testing Results}

Islamic samples

The results suggest that pro-environmental identity (H1 ISLAM: $\beta=0.416, p<0.01$ ), attitudes toward environmental issues (H2 ISLAM: $\beta=0.201, p<0.01$ ), and subjective norms about the environment positively influenced consumer intention to purchase green products (H3 ISLAM: $\beta=0.298, p<0.01)$. Thus, $\mathrm{H} 1_{\text {ISLAM, }} \mathrm{H} 2$ ISLAM, and $\mathrm{H} 3$ ISLAM $_{\text {are }}$ all supported.

Furthermore, Intrinsic religiousness positively influences pro-environmental identity (H4 ISLAM: $\beta=0.292, p<0.01$ ), attitudes toward environmental issues (H5 IsLAM: $\beta=0.248, p$ $<0.01$ ), and subjective norms about the environment (H6 ISLAM: $\beta=0.278, p<0.01$ ). Hence, H4 ISLAM, H5 ISLAM, and H6 ISLAM are all supported. Finally, from the perspective of extrinsic religiousness, our results show that $\mathrm{H} 8$ is supported. Extrinsic religiousness negatively affects consumer attitudes toward environmental issues (H8 ISLAM: $\beta=-0.158, p<0.01$ ). However, H7 ISLAM and H9 ISLAM are not supported. Extrinsic religiousness did not affect consumer proenvironmental identity and subjective norms about the environment.

Christian samples

Similar to the Muslims' consumers, H1 Christian, H2 CHRISTIAN, and H3 CHRISTIAN are supported. The results suggest that pro-environmental identity (H1 CHRISTIAN: $\beta=0.449, p<$ 0.01 ), attitudes toward environmental issues ( $\mathrm{H} 2$ CHRISTIAN: $\beta=0.212, p<0.01$ ), and subjective norms about the environment positively influence consumer intention to purchase green products (H3 CHRISTIAN: $\beta=0.341, p<0.01)$.

Furthermore, the results reveal that $\mathrm{H} 4$ CHRISTIAN, $\mathrm{H} 5$ CHRISTIAN and $\mathrm{H} 6$ CHRISTIAN are supported. Intrinsic religiousness positively affects pro-environmental identity (H4 CHRISTIAN: 
$\beta=0.293, p<0.01)$ attitudes toward environmental issues (H5 CHRISTIAN: $\beta=0.237, p<0.01$ ), and subjective norms about the environment (H6 CHRISTIAN: $\beta=0.315, p<0.01)$. Moreover, extrinsic religiousness positively influences consumer pro-environmental identity (H4 $4_{\text {ChRISTIAN: }} \beta=0.129, p<0.01$ ). Thus, $\mathrm{H} 7$ is not supported due to its opposite direction. Subsequently, H8 Christian and $\mathrm{H} 9$ ChRISTIAN are not supported. The effect of extrinsic religiousness on attitudes toward environmental issues and subjective norms about the environment were not significant. Tables 5 and 6 summarize the hypothesis testing results.

\section{Insert Tables 5 and 6 about Here}

\section{Discussion and Implications}

Similarities between religions

The main findings indicate consistent positive impacts of intrinsic religiousness on proenvironmental identity, consumer attitudes toward environmental issues, and subjective norms about the environment across both Muslim and Christian consumers in Indonesia. Previous studies have shown that people with high intrinsic religiousness tend to have more concern with higher ethical or moral standards (Arli and Tjiptono 2014; Minton et al. 2015; Vitell, et al. 2005; Weibe and Fleck 1980). The present study reveals that religious consumers see themselves as someone who cares about the environment. They see earth as God's creation and are willing to sustain it. Moreover, intrinsic religiousness also positively influences subjective norms about the environment. As a result of living in a religious community, consumers constantly receive opinions, ideas, and suggestions from others, especially their religious leaders. In many cases, the religious leaders are often people they look up to. Consequently, in order to deliver an effective message to increase people's concern and awareness of the environment, government and other environmental agencies can work with these leaders to promote pro-environmentally friendly behavior. Approval by 
religious leaders is an important part to promoting any behavior, as their approval often is interpreted as an approval from 'God.'

Another consistent finding across the two religion samples is that pro-environmental identity, attitudes toward environmental issues, and subjective norms about the environment positively influence consumer intention to purchase green products. Higher intention to buy environmentally friendly products will be found among those who perceive themselves as environmentally-friendly consumers, have positive attitudes toward environmental issues, and perceive a high degree of social pressures to purchase green products. In the current study, the proxy used for responsible consumption is purchase intention of environmentally friendly household products - which are easily found in most supermarkets and minimarkets in Indonesia.

\section{Differences between religions}

The differences between religions are found in the role of extrinsic religiousness. For Muslim consumers in Indonesia, extrinsic religiousness had a negative effect on attitudes toward environmental issues but insignificant impacts on pro-environmental identity and subjective norms about the environment. Those who view religious activity as "a means to other personal and potentially more selfish ends" (Ghorbani et al. 2002, p. 70) tend to have more negative attitudes toward environmental issues. The inconsistent results of the role of extrinsic religiousness may suggest that it is a complex phenomenon (Ghorbani et al. 2002), where it can have positive as well as negative impacts (Pargament, 1992) and it has a very limited impact on ethical behavior (Vitell, 2014). It seems that there is a clear distinction between intrinsic and extrinsic religiousness for Muslim consumers. Extrinsic religiousness is either a non-significant or a negatively significant determinant of self-identity, attitudes, and 
subjective norms about the environment. In contrast, for Christian's consumers in Indonesia, extrinsic religiousness positively affects consumers' pro-environmental identity but not their attitudes toward environmental issues and subjective norms about the environment. These results also indicate differences between religious and non-religious consumers. The study supports the idea that religiousness can affect consumer behavior, influence managerial action, and promote change (Engelland 2014; Minton et al. 2015; Njoh 2012). The present study highlights the importance of religiousness when exploring consumers' attitude toward green marketing and purchase intention of green products, especially for consumers living in a religious society. Irrespective of religions, consumers with high intrinsic religiousness are more likely to display positive attitude toward the environment. The results show the importance of collaboration between government, businesses, and religious institutions to reach and improve consumers' awareness on the importance of environmental sustainability and subsequently supporting a green cause.

Recently there is a growing "authentic Islamic environmental movement" in a number of Muslim countries, including Indonesia (Nasr, cited in Wihbey 2012). In Indonesia, Muslim organizations have long been one of the most important key drivers for social and political change (Brownlee, 2009). The two largest mass-based Islamic organizations, Nahdlatul Ulama (NU) and Muhammadiyah, have shown their concerns about environmental issues by establishing national and local bodies dedicated to the environment. Actions taken include training their religious leaders on knowledge of environmental issues and instilling curriculum on environmental issues in Islamic schools from elementary school to university level (Simamora 2010). Such initiatives may be influential in creating or reinforcing positive attitudes towards environmental issues, stronger subjective norms about the environment, and stronger pro-environmental beliefs. This is relevant due to the fact that many studies have 
indicated that Muslim organizations have been perceived to be the most legitimate institution that Indonesians trust (Brownlee 2009).

Similarly, the Catholic Church has long highlighted the importance of the protection and care of the environment. For instance, all quotations about the environment from Pope Benedict XVI (2012) were published in a book by Our Sunday Visitor. The Catholic Church in Indonesia has initiated many programs (e.g., education, negotiation, and advocacy) for several community groups (Dokumen Gereja Katolik 2013). The Bishops’ Conference of Indonesia (Konferensi Waligereja Indonesia $=$ KWI) issued a pastoral memorandum on the Church's involvement in preserving God's creation (Dokumen Gereja Katolik 2013). The most recent publication of "Encyclical Letter Laudato Si' of the Holy Father Francis on Care for Our Common Home" presents the Catholic Church position on environment and sustainability (Pope Francis 2015). Pope Francis pointed out the importance of religious institution in raising people awareness toward the environment: "All Christian communities have an important role to play in ecological education. It is my hope that our seminaries and houses of formation will provide an education in responsible simplicity of life, in grateful contemplation of God's world, and in concern for the needs of the poor and the protection of the environment" (Pope Francis, 2015, p. 156). Ignoring individuals' religiousness will eventually reduce the effectiveness of a program or campaign toward these consumers.

\section{Limitation and Future Research}

Despite some important findings, there are some caveats in interpreting the results.

Environmental concern in general and green behavior in particular is a complex issue. A 2010 Pew Global Attitudes survey found that about $61 \%$ of the Indonesian respondents believed that protecting the environment should be prioritized despite the potential costs (slower economic growth and job cuts) (Pew Research Center 2010). However, when asked 
about their willingness to pay higher prices to address climate change, only $32 \%$ of the Indonesian respondents agreed to do so. Other studies in different countries found an attitudebehavior gap, where positive attitude towards the environment does not translate into green purchase behavior (Follows and Jobber 2000; Fraj and Martinez 2007; Mostafa 2007; Young et al. 2010). Several strategies have been proposed to overcome the gap, including "social normalization" to make green behavior (e.g. buying environmentally-friendly household products, taking own shopping bags to the shops, and using energy-saving light bulbs) 'normal', i.e. "what most people generally do" (Rettie, Burchell and Barnham 2014, p. 9; Rettie, Burchell and Riley 2012, p. 421). Thus, future research may investigate the gap between attitude and behavior in regards to sustainable consumption.

Moreover, the data employed are cross-sectional in one country, thus definitive statements about causal relationships between variables cannot be made. The religion profile of the sample differs from the actual populations, where only $36.2 \%$ of Muslim respondents participated. Therefore, the generalizability of the study may be limited. Nevertheless, since the focus of the study is to examine the impact of religiousness on consumers' identity, attitudes and their subjective norms, the study can provide useful insights into the comparison of the influences within the Muslim and Christian samples. Future research may investigate other religions, such as Buddhism and Hinduism. Other comparisons may also be conducted, such as religious versus nonreligious consumers, cross-national study, and so forth. Moreover, the study did not look at the impact of income and education, as we are focusing on individuals' religiousness. Future research may investigate the impact of these demographics, in regard to religion, on their intention to purchase green products especially in regards to their willingness to pay. 


\section{References}

Ajzen, I. (1985). From Intentions to Actions: A Theory of Planned Behaviour. In Kuhl, J. and Beckmann, J. (Eds), From Cognition to Behavior. New York: Springer, 11-39.

Allport, G. W. (1950). The Individual and His Religion: A Psychological Interpretation. New York: MacMillan.

Allport, G. W. and Ross, J. M. (1967). Personal religious orientation and prejudice. Journal of Personality and Social Psychology, 5, 447-457.

Aminzadeh, B. (2013). Religious ideology and environment: An introduction to Islamic approach to nature. Hekmat Quarterly Journal: An International Journal of Academic Research, Winter, 6, 17-31.

Amyx, D. A., DeJong, P. F., Lin, X., Chakraborty, G., \& Wiener, J. L. (1994). Influencers of purchase intentions for ecologically safe products: An exploratory study.

In Marketing Theory and Applications: The Proceedings of the 1994 American Marketing Association's Winter Educator's Conference, 5, 341-347.

Ajzen, I., \& Fishbein, M. (1980). Understanding attitudes and predicting social behaviour. Anderson, J. C., \& Gerbing, D. W. (1988). Structural equation modeling in practice: A review and recommended two-step approach. Psychological Bulletin, 103(3), 411423.

Arli, D., \& Tjiptono, F. (2014). The end of religion? Examining the role of religiousness, materialism, and long-term orientation on consumer ethics in Indonesia. Journal of Business Ethics, 123(3), 385-400.

Arli, D., \& Lasmono, H. (2015). Are religious people more caring? Exploring the impact of religiosity on charitable organizations in a developing country.International Journal of Nonprofit and Voluntary Sector Marketing, 20(1), 38-51.

Bailey, J. M., \& Sood, J. (1993). The effects of religious affiliation on consumer behavior: A preliminary investigation. Journal of Managerial Issues, 5(3), 328-352.

Bamberg, S. (2003). How does environmental concern influence specific environmentally related behaviors? A new answer to an old question. Journal of Environmental Psychology, 23(1), 21-32

Banerjee, S., Gulas, C. S., \& Iyer, E. (1995). Shades of green: A multidimensional analysis of environmental advertising. Journal of Advertising, 24(2), 21-31.

Banarjee, B., \& McKeage, K. (1994). How green is my value: Exploring the relationship between environmentalism and materialism. Advances in Consumer Research, 21, 147-147.

Bazzi, K. (2013). A reflection on sustainable environment in Islamic world. Hekmat Quarterly Journal, 6, 77-80.

Biel, A., \& Nilsson, A. (2005). Religious values and environmental concern: Harmony and detachment. Social Science Quarterly, 86, 178-191.

Bohlen, G., Schlegelmilch, B. B., \& Diamantopoulos, A. (1993). Measuring ecological concern: A multi-construct perspective. Journal of Marketing Management, 9(4), 415430.

Brownlee, J. (2009). In Indonesia: Islamic organizations go green. Source: http://asiafoundation.org/in-asia/2009/06/03/in-indonesia-islamic-organizations-gogreen/

Casidy, R., Phau, I., \& Lwin, M. (2016). Religiosity and Digital Piracy: An Empirical Examination. Services Marketing Quarterly, 37(1), 1-13.

CIA (2015). Indonesia-The world factbook. Source: https://www.cia.gov/library/publications/resources/the-world-factbook/geos/id.html

Cleveland, M., Kalamas, M., \& Laroche, M. (2005). Shades of green: Linking environmental 
locus of control and pro-environmental behaviors. Journal of Consumer Marketing, 22(4), 198-212.

Coddington, W. (1993). Environmental Marketing: Positive Strategies for Reaching Green Consumers. New York: McGraw-Hill.

Cook, A. J., Kerr, G. N., \& Moore, K. (2002). Attitudes and intentions towards purchasing GM food. Journal of Economic Psychology, 23(5), 557-572.

CNN (2015). The world's fastest-growing religion is... Source: http://edition.cnn.com/2015/04/02/living/pew-study-religion/

Cui, J., Jo, H., \& Velasquez, M. G. (2014). The influence of Christian religiosity on managerial decisions concerning the environment. Journal of Ethics, DOI 10.1007/s10551-014-2306-5.

das Neves, J. C., \& Melé, D. (2013). Managing ethically cultural diversity: Learning from Thomas Aquinas. Journal of Business Ethics, 116(4), 769-780.

Delener, N. (1994). Religious contrasts in consumer decision behaviour patterns: Their dimensions and marketing implications. European Journal of Marketing, 28(5), 3653.

Diener, E., Tay, L., \& Myers, D. G. (2011). The religion paradox: If religion makes people happy, why are so many dropping out? Journal of Personality and Social Psychology, 101(6), 1278-1290.

Djupe, P.A., \& Gwiasda, G.W. (2010). Evangelizing the environment: Decision process effects in political persuasion. Journal for the Scientific Study of Religion, 49(1), 7386.

Dokumen Gereja Katolik (2013). Nota pastoral KWI tahun 2013: "Keterlibatan Gereja dalam melestarikan keutuhan ciptaan". Source: http://dokumengerejakatolik.blogspot.com/2013/04/nota-pastoral-kwi-tahun2013.html

Donahue, M. J. (1985). Intrinsic and extrinsic religiousness: Review and meta analysis. Journal of Personality and Social Psychology, 48(2), 400-419.

Eckberg, D.L., \& Blocker, T.J. (1989). Varieties of religious involvement and environmental concerns: Testing the Lynn White thesis. Journal for the Scientific Study of Religion, 28(4), 509-517.

Eckberg, D. L., \& Blocker, T. J. (1996). Christianity, environmentalism, and the theoretical problem of fundamentalism. Journal for the Scientific Study of Religion, 35(4), 343355.

Engelland, B. T. (2014). Religion, humanism, marketing, and the consumption of socially responsible products, services, and ideas: Introduction to a special topic section. Journal of Business Research, 67(2), 1-4.

Essoo, N., \& Dibb, S. (2004). Religious influences on shopping behaviour: An exploratory study. Journal of Marketing Management, 20(7-8), 683-712.

Fishbein, M., \& Ajzen, I. (1975). Belief, Attitude, Intention and Behavior: An Introduction to Theory and Research. Reading, MA: Addison-Wesley.

Fekadu, Z., \& Kraft, P. (2001). Self-identity in planned behavior perspective: Past behavior and its moderating effects on self-identity-intention relations. Social Behavior and Personality, 29(7), 671-686.

Follows, S. B., \& Jobber, D. (2000). Environmentally responsible purchase behavior: A test of a consumer model. European Journal of Marketing, 34(5/6), 723-746.

Fraj, E., \& Martinez, E. (2007). Ecological consumer behavior: An empirical analysis. International Journal of Consumer Studies, 31(1), 26-33.

Fujii, S., and Taniguchi, A. (2006). Determinants of the effectiveness of travel feedback programs - a review of communicative mobility management measures for changing travel behavior in Japan. Transport Policy, 13, 339-348. 
Gadenne, D., Sharma, B., Kerr, D., \& Smith, T. (2011). The influence of consumers' environmental beliefs and attitudes on energy saving behaviours. Energy Policy, 39(12), 7684-7694.

Ghorbani, N., Watson, P. J., Ghramaleki, A. F., Morris, R. J., \& Hood Jr., R. W. (2002). Muslim-Christian religious orientation scales: Distinctions, correlations, and crosscultural analysis in Iran and the United States. The International Journal for the Psychology of Religion, 12(2), 69-91.

Granzin, K. L., \& Olsen, J. E. (1991). Characterizing participants in activities protecting the environment: A focus on donating, recycling, and conservation behaviors. Journal of Public Policy \& Marketing, 10(2), 1-27.

Grunert, S. \& Kristensen, K. (1991). On some factors influencing consumers' demand for organically grown foods. In. R.N. Mayer (Ed.), Enhancing Consumers' Choice. Columbia, MI: ACCI, 37-48.

Grunert, S. C. (1993). Green consumerism in Denmark: Some evidence from the ØKO foods -project. der markt, 32(3), 140-151.

Guagnano, G. A. (1995). Locus of control, altruism and agentic disposition. Population and Environment, 17(1), 63-77.

Guth, J. L., Green, J. C., Kellstedt, L. A., \& Smidt, C. E. (1995). Faith and the environment: Religious beliefs and attitudes on environmental policy. American Journal of Political Science, 39(2), 364-382.

Hair, J. F., Black, W. C., Babin, B. J., Anderson, R. E., \& Tatham, R. L. (2006). Multivariate data analysis (Vol. 6). Upper Saddle River, NJ: Pearson Prentice Hall.

Hirschman, E. C. (1983). Religious affiliation and consumption processes: An initial paradigm. Research in Marketing, 6, 131-170.

Hirschman, E.C., Ruvio, A.A., \& Touzani, M. (2011). Breaking bread with Abraham's children: Christians, Jews and Muslims' holiday consumption in dominant, minority and diasporic communities. Journal of the Academy of Marketing Science, 39(3), 429-448.

Hu, L. T., \& Bentler, P. M. (1999). Cutoff criteria for fit indexes in covariance structure analysis: Conventional criteria versus new alternatives. Structural Equation Modeling: A Multidisciplinary Journal, 6(1), 1-55.

Indonesia-Investments (2015). Christianity in Indonesia. Source: http://www.indonesia investments.com/culture/religion/christianity/item 249

Jager, W. (2006). Stimulating the diffusion of photovoltaic systems: A behavioural perspective. Energy Policy, 34(14), 1935-1943.

James, W. (1902/2004). The varieties of religious experience. New York: Touchstone.

Kalamas, M., Cleveland, M., \& Laroche, M. (2014). Pro-environmental behaviors for thee but not for me: Green giants, green Gods, and external environmental locus of control. Journal of Business Research, 67(2), 12-22.

Kanagy, C. L., \& Willits, F. K. (1993). A" greening" of religion? Some evidence from a Pennsylvania sample. Social Science Quarterly, 74(3), 674-683.

Kim, H. Y., \& Chung, K. J-E. (2011). Consumer purchase intention for organic personal care products. Journal of Consumer Marketing, 28(1), 40-47.

Kearns, L. (1997). Noah's ark goes to Washington: A profile of evangelical environmentalism. Social Compass, 44, 349-366.

Klockner, C. A. (2013). A comprehensive model of the psychology of environmental behaviour-A meta-analysis. Global Environmental Change, 23, 1028-1038.

Kohut, A. (2001). The Diminishing Divide: Religion's Changing Role in American Politics. Brookings Institution Press. Washington, DC.

Laroche, M., Bergeron, J., \& Barbaro-Forleo, G. (2001). Targeting consumers who are 
willing to pay more for environmentally friendly products. Journal of Consumer Marketing, 18(6), 503-520.

Martin, W. C., \& Bateman, C. R. (2014). Consumer religious commitment's influence on ecocentric attitudes and behavior. Journal of Business Research, 67(2), 5-11.

McCarty, J. A., \& Shrum, L. J. (2001). The influence of individualism, collectivism, and locus of control on environmental beliefs and behavior. Journal of Public Policy \& Marketing, 20(1), 93-104.

Mainieri, T., Barnett, E., Valdero, T., Unipan, J., \& Oskamp, S. (1997). Green buying: The influence of environmental concern on consumer behaviour. Journal of Social Psychology, 137, 189-204.

Marinova, D., Hossain, A., \& Hossain-Rhaman, P. (2008). Islam on sustainability. International Journal of Environmental, Cultural, Economic and Social Sustainability, 4, 123-130.

Mathieu, J. E., \& Taylor, S. R. (2006). Clarifying conditions and decision points for mediational type inferences in organizational behavior. Journal of Organizational Behavior, 27(8), 1031-1056.

Melé, D. (2003). The challenge of humanistic management. Journal of Business Ethics, 44(1), 77-88.

Mele, D. (2006). Religious foundations of business ethics. The Accountable Corporation: Business Ethics, 2, 11-43.

Melé, D. (2009). Integrating personalism into virtue-based business ethics: The personalist and the common good principles. Journal of Business Ethics, 88(1), 227-244.

Merchant, C. (2003). Racial Ecology. London: Routledge.

Merrit, J., Mohler, R. A., \& Beisner, C. (2010). Green plus Christian isn't new math. Source: http://www.christianitytoday.com/ct/2010/june/26.46.html

Minton, E.A., \& Kahle, L.R. (2013). Belief systems, religion, and behavioral economics: Marketing in multicultural environments. New York, NY: Business Expert Press.

Minton, E. A., Kahle, L. R., \& Kim, C. H. (2015). Religion and motives for sustainable behaviors: A cross-cultural comparison and contrast. Journal of Business doi.org/10.1016/j.jbusres.2015.01.003.

Mostafa, M. M. (2007). A hierarchical analysis of the green consciousness of the Egyptian consumer. Psychology \& Marketing, 24(5), 445-473.

Njoh, A. J. (2012). The impact of religion on women empowerment as a millennium development goal in Africa. Social Indicators Research, 107(1), 1-18.

Ozaki, R. (2011). Adopting sustainable innovation: What makes consumers sign up to green electricity?. Business Strategy and the Environment, 20(1), 1-17.

Ozaki, R., \& Sevastyanova, K. (2011). Going hybrid: An analysis of consumer purchase motivations. Energy Policy, 39(5), 2217-2227.

Pargament, K. I., Kennell, J., Hathaway, W., Grevengoed, N., Newman, J., \& Jones, W. (1988). Religion and the problem-solving process: Three styles of coping. Journal for the Scientific Study of Religion, 90-104.

Peart, J. (2010). Green marketing: Making sense of the situation. Academy of Marketing Studies, 15(1), 68-76.

Peattie, K. (2010). Green consumption: Behavior and norms. Annual Review of Environment and Resources, 35, 195-228.

Pew Research Center (2010). Chapter 8. Environmental Issues. Source: http://www.pewglobal.org/2010/06/17/chapter-8-environmental-issues-2/

Pew Research (2015). The Future of World Religions: Population Growth Projections, 2010 -2050. Source: http://www.pewforum.org/2015/04/02/religious-projections-2010$2050 /$ 
Pickett-Baker, J., \& Ozaki, R. (2008). Pro-environmental products: Marketing influence on consumer purchase decision. Journal of Consumer Marketing, 25(5), 281-293.

Pope Benedict XVI (2012). The Environment. Huntington, IN: Our Sunday Visitor.

Pope Francis (2015). Encyclical Letter Laudato Si' of the Holy Father Francis on Care for Our Common Home. Source:

http://w2.vatican.va/content/dam/francesco/pdf/encyclicals/documents/papafrancesco 20150524 enciclica-laudato-si en.pdf.

Rettie, R., Burchell, K., \& Riley, D. (2012). Normalising green behaviours: A new approach to sustainability marketing. Journal of Marketing Management, 28(3-4), 420-444.

Rettie, R., Burchell, K., \& Barnham, C. (2014). Social normalisation: Using marketing to make green normal. Journal of Consumer Behaviour, 13, 9-17.

Robinson, T. (2010). The biblical mandate for creation care. In Moore, K. D., \& Nelson, M. P. (Eds). Moral Ground: Ethical Action for a Planet in Peril. Trinity University Press, San Antonio.

Schreck, A. (2004). Catholic and Christian: An Explanation of Commonly Misunderstood Catholic Beliefs. St. Anthony Messenger Press, USA.

Schultz, T. Shriver, C., Tabanico, J., \& Khazian, A. (2004). Implicit connection with nature. Journal of Environmental Psychology, 24, 31-42.

Schultz, P., Zelezny, L., \& Dalrymple, N. J. (2000). A multinational perspective on the relation between Judeo-Christian religious beliefs and attitudes of environmental concern. Environment and Behavior, 32(4), 576-591.

Schwarte, C. (1992). Environmental protection in Islamic law: An overview on potential influences for legal developments in Iraq. Local Environment, 8, 567-576.

Sherkat, D. E., \& Ellison, C. G. (2007). Structuring the religion-environment connection: Identifying religious influences on environmental concern and activism. Journal for the Scientific Study of Religion, 46, 71-85.

Sidiras, D. K., \& Koukios, E. G. (2004). Solar systems diffusion in local markets. Energy Policy, 32(18), 2007-2018.

Simamora, A.P. (2010). Muslim leaders told to confront climate crisis. http://www.thejakartapost.com/news/2010/04/11/muslim-leaders-told-confrontclimate-crisis.html

Simmons, D. \& Widmar, R. (1990). Motivations and barriers to recycling: Toward a strategy for public education. Journal of Environmental Education, 22, 13-18.

Smith, N., \& Leiserowitz, A. (2013). American evangelicals and global warming. Global Environmental Change, 23(5), 1009-1017.

Sparks, P., \& Shepherd, R. (1992). Self-identity and the theory of planned behavior: Assessing the role of identification with "green consumerism". Social Psychology Quarterly, 55(4), 388-399.

Sparks, P., Shepherd, R., \& Frewer, L. J. (1995). Assessing and structuring attitudes toward the use of gene technology in food production: The role of ethical obligation. Basic and Applied Social Psychology, 16(3), 267-285.

Swimberghe, K., Sharma, D., \& Flurry, L. (2009). An exploratory investigation of the consumer religious commitment and its influence on store loyalty and consumer complaint intentions. Journal of Consumer Marketing, 26(5), 340-347.

Tanner, C., \& Wölfing Kast, S. (2003). Promoting sustainable consumption: Determinants of green purchases by Swiss consumers. Psychology \& Marketing, 20(10), 883-902.

Terry, D. J., Hogg, M. A., \& White, K. M. (1999). The theory of planned behaviour: Self identity, social identity and group norms. British Journal of Social Psychology, 38, $225-244$.

The Interfaith Center for Sustainable Development (2015). Pope Benedict XVI on the 
environment. Source: http://www.interfaithsustain.com/pope-benedict-xvi-on-theenvironment/

Vitell, S. J., Paolillo, J. G. P., \& Singh, J. J. (2005). Religiosity and consumer ethics. Journal of Business Ethics, 57, 175-181.

Vitell, S. J. (2014). A case for consumer social responsibility (CnSR): Including a selected review of consumer ethics/social responsibility research. Journal of Business Ethics, 1-8. doi: 10.1007/s10551-014-2110-2.

Watson, P. J., Hood, R. W., Morris, R. J., \& Hall, J. R. (1987). The relationship between religiosity and narcissism. Counselling and Values, 31(2) 179-184.

Webster Jr, F. E. (1975). Determining the characteristics of the socially conscious consumer. Journal of Consumer Research, 2(3), 188-196.

Weibe, K. F., \& Fleck, J. R. (1980). Personality correlates of intrinsic, extrinsic and non -religious orientations. Journal of Psychology, 105, 181-187.

Whitley Jr, B. E. (2009). Religiosity and attitudes toward lesbians and gay men: A meta -analysis. International Journal for the Psychology of Religion,19(1), 21-38.

Whitmarsh, L., \& O'Neill, S. (2010). Green identity, green living? The role of proenvironmental self-identity in determining consistency across diverse proenvi ronmental behaviors. Journal of Environmental Psychology, 30, 305-314.

Wihbey, J. (2012). 'Green Muslims', eco-Islam and evolving climate change consciousness. Source: http://www.yaleclimateconnections.org/2012/04/green-muslims-eco-islamand-evolving-climate-change-consciousness/

Wills, G. (1991). Under God: Religion and American Politics. Touchstone, New York.

Wilkes, R. E., Burnett, J. J., \& Howell, R. D. (1986). On the meaning and measurement of religiosity in consumer research. Journal of the Academy of Marketing Science, 14(1), 47-56.

Woodrum, E., \& Wolkomir, M. J. (1997). Religious effects on environmentalism. Sociological Spectrum, 17(2), 223-234.

Wolkomir, M., Futreal, M., Woodrum, E., \& Hoban, T. (1997). Substantive religious belief and environmentalism. Social Science Quarterly, 78(1), 96-108.

Worthington Jr, E. L., Wade, N. G., Hight, T. L., Ripley, J. S., McCullough, M. E., Berry, J. W., Schmitt, M. Berry, J., Bursley, K. H. \& O'Connor, L. (2003). The religious commitment inventory-10: Development, refinement, and validation of a brief scale for research and counseling. Journal of Counseling Psychology, 50(1), 84-93.

Young, W., Hwang, K., McDonald, S., \& Oates, C. J. (2010). Sustainable consumption: Green consumer behavior when purchasing products. Sustainable Development, 18(1), 21-31.

Zafar, S. (2014). Environmental sustainability in Islam. Source: http://www.ecomena.org/sustainability-islam/

Zinnbauer, B. J., Pargament, K. I., Cole, B., Rye, M. S., Butter, E. M., Belavich, T. G., Hipp, K. M., Scott, A. B., \& Kadar, J. L. (1997). Religion and spirituality: Unfuzzying the fuzzy. Journal for the Scientific Study of Religion, 36 (4), 549-564. 


\section{Appendix}

Figure 1. Research Model

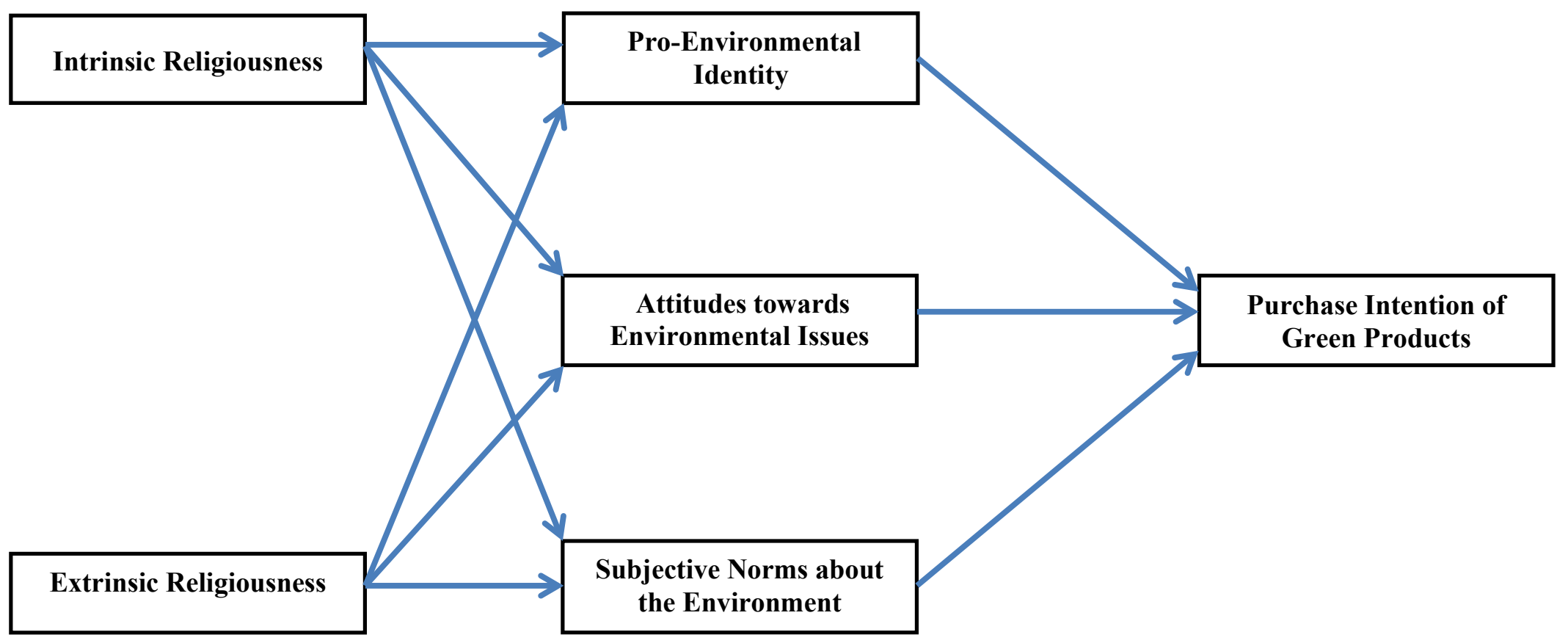


Table 1. Demographic Profiles of Samples

\begin{tabular}{|c|c|}
\hline Demographic & Percentage \\
\hline Age & \\
\hline$<18$ years old & $2.5 \%$ \\
\hline $18-20$ years old & $27.9 \%$ \\
\hline $21-23$ years old & $16.5 \%$ \\
\hline $24-26$ years old & $16.2 \%$ \\
\hline$>26$ years old & $37.0 \%$ \\
\hline Gender & \\
\hline Male & $45.8 \%$ \\
\hline Female & $54.2 \%$ \\
\hline Marital Status & \\
\hline Single & $61.9 \%$ \\
\hline Married & $34.4 \%$ \\
\hline Other & $3.7 \%$ \\
\hline Religion $*$ & $36.2 \%$ \\
\hline Islam & $63.8 \%$ \\
\hline Christianity & \\
\hline consis of $86.1 \%$ & \\
\hline
\end{tabular}

Note: *Indonesia consists of $86.1 \%$ Muslim, followed by $8.7 \%$ Protestant/Catholic, $3 \%$ Hindu, and $1.8 \%$ others 
Table 2. Correlations and Descriptive Statistics (ISLAM)

\begin{tabular}{|c|c|c|c|c|c|c|}
\hline$n=235$ & 1 & 2 & 3 & 4 & 5 & 6 \\
\hline 1. Intrinsic Religiousness & 1 & & & & & \\
\hline 2. Extrinsic Religiousness & $0.449 * *$ & 1 & & & & \\
\hline 3. Pro-Environmental Identity & -0.196 & -0.201 & 1 & & & \\
\hline 4. Attitudes towards Environmental Issues & -0.123 & -0.257 & $0.415^{* *}$ & 1 & & \\
\hline 5. Subjective Norms & 0.368 & 0.034 & $0.463^{* *}$ & $0.352 * *$ & 1 & \\
\hline 6. Purchase Intention of Green Products & -0.304 & 0.151 & $0.560 *$ & $0.518^{*}$ & 0.020 & 1 \\
\hline $\mathrm{M}$ & 4.15 & 2.61 & 3.43 & 3.34 & 4.01 & 3.37 \\
\hline SD & 0.68 & 1.03 & 0.63 & 0.66 & 0.64 & 0.72 \\
\hline
\end{tabular}

${ }^{* *} p<0.01 ;{ }^{*} p<0.05$

Table 3. Correlations and Descriptive Statistics (CHRISTIANITY)

\begin{tabular}{|c|c|c|c|c|c|c|}
\hline$n=414$ & 1 & 2 & 3 & 4 & 5 & 6 \\
\hline 1. Intrinsic Religiousness & 1 & & & & & \\
\hline 2. Extrinsic Religiousness & -0.023 & 1 & & & & \\
\hline 3. Pro-Environmental Identity & $0.193 *$ & -0.052 & 1 & & & \\
\hline 4. Attitudes towards Environmental Issues & 0.076 & -0.249 & $0.250 * *$ & 1 & & \\
\hline 5. Subjective Norms & $0.235^{* *}$ & -0.053 & $0.499 * *$ & $0.175^{* *}$ & 1 & \\
\hline 6. Purchase Intention of Green Products & $0.156^{*}$ & -0.050 & $0.425^{* *}$ & $0.175^{*}$ & $0.470 * *$ & 1 \\
\hline $\mathrm{M}$ & 4.00 & 2.41 & 3.35 & 3.33 & 4.18 & 3.08 \\
\hline SD & 0.61 & 0.93 & 0.62 & 0.70 & 0.53 & 0.64 \\
\hline
\end{tabular}

$* * p<0.01 ; * p<0.05$ 
Table 4. Scale Items

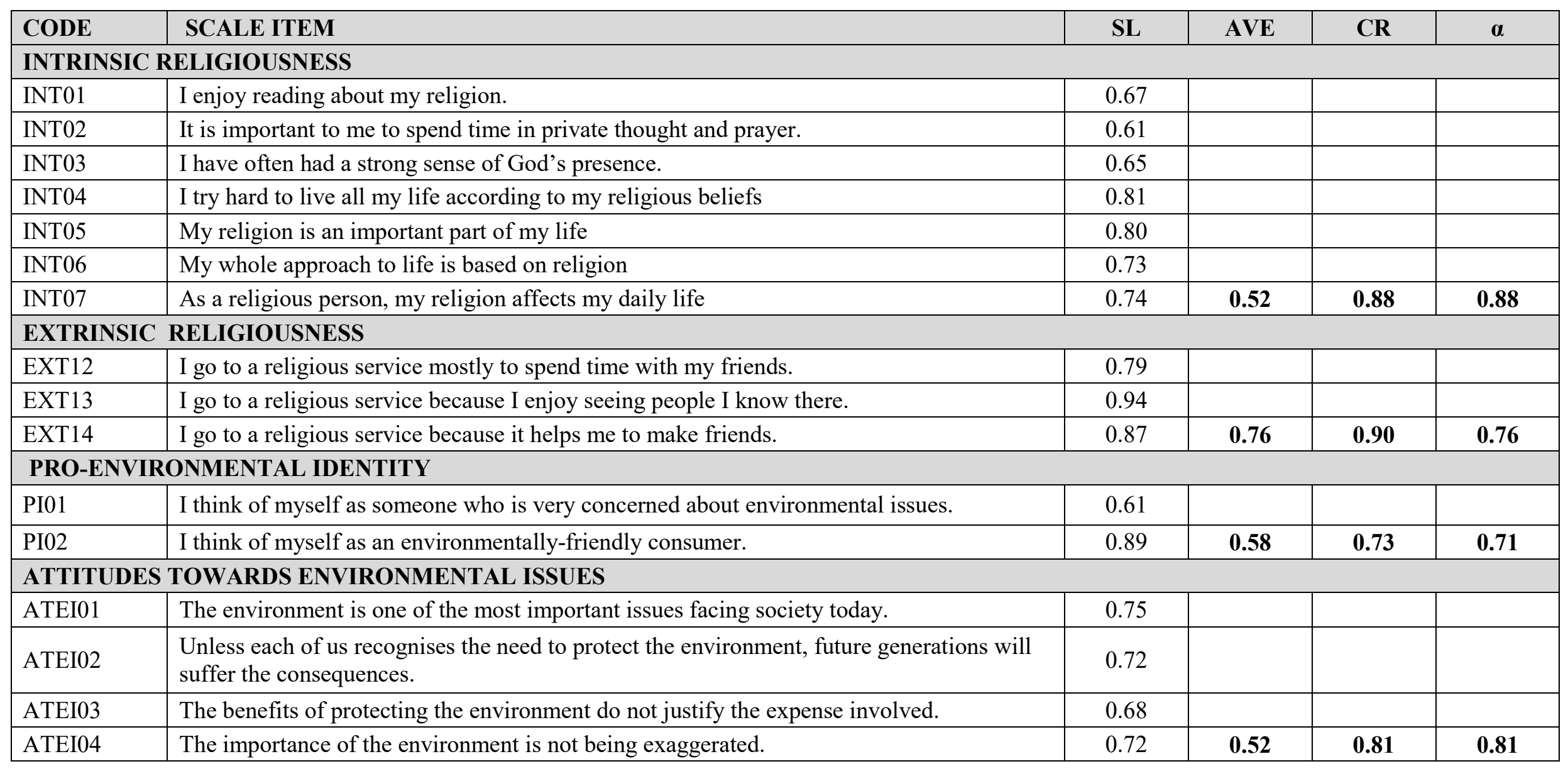


Table 4. Scale Items (continued)

\begin{tabular}{|l|l|c|c|c|c|}
\hline CODE & SCALE ITEM & SL & AVE & CR & \multicolumn{3}{|c|}{$\alpha$} \\
\hline SUBJECTIVE NORMS ABOUT THE ENVIRONMENT & 0.78 & \\
\hline SN01 & Most people who are important to me buy environmentally-friendly household products. & & \\
\hline SN02 & $\begin{array}{l}\text { Most people who are important to me are concerned about issues related to the } \\
\text { environment. }\end{array}$ & 0.85 & & \\
\hline SN03 & $\begin{array}{l}\text { Most people who are important to me think it is important to buy environmentally-friendly } \\
\text { household products. }\end{array}$ & 0.86 & $\mathbf{0 . 6 9}$ & $\mathbf{0 . 8 7}$ & $\mathbf{0 . 8 6}$ \\
\hline INTENTION TO PURCHASE GREEN PRODUCTS & $\begin{array}{l}\text { In the next six weeks, how likely are you to purchase environmentally-friendly household } \\
\text { products? }\end{array}$ & 0.82 & & \\
\hline ITPGP01 & I intend to buy environmentally-friendly household products during the next six weeks. & 0.61 & $\mathbf{0 . 5 2}$ & $\mathbf{0 . 6 8}$ & $\mathbf{0 . 7 8}$ \\
\hline ITPGP02 &
\end{tabular}


Table 5. Model Estimates (ISLAM)

\begin{tabular}{|c|c|c|c|c|}
\hline & & $\begin{array}{l}\text { Standardized parameter } \\
\text { estimates (Std. Errors) }\end{array}$ & $\begin{array}{l}\text { Hypothesized } \\
\text { Effects }\end{array}$ & $\begin{array}{l}\text { Hypothesis } \\
\text { Testing } \\
\text { Results }\end{array}$ \\
\hline H1 ISLAM & Pro-environmental identity $\rightarrow$ Purchase Intention & $0.416 * *(0.059)$ & $(+)$ & Supported \\
\hline H2 ISLAM & $\begin{array}{l}\text { Attitudes towards environmental issues } \rightarrow \text { Purchase } \\
\text { Intention }\end{array}$ & $0.201 * *(0.058)$ & $(+)$ & Supported \\
\hline H3ISLAM & $\begin{array}{l}\text { Subjective norms about the environment } \rightarrow \text { Purchase } \\
\text { Intention }\end{array}$ & $0.298 * *(0.041)$ & $(+)$ & Supported \\
\hline H4ISLAM & Intrinsic Religiousness $\rightarrow$ Pro-environmental identity & $0.292 * *(0.036)$ & $(+)$ & Supported \\
\hline H5ISLAM & $\begin{array}{l}\text { Intrinsic Religiousness } \rightarrow \text { Attitudes towards } \\
\text { environmental issues }\end{array}$ & $0.248 * *(0.032)$ & $(+)$ & Supported \\
\hline H6ISLAM & $\begin{array}{l}\text { Intrinsic Religiousness } \rightarrow \text { Subjective norms about the } \\
\text { environment }\end{array}$ & $0.278 * *(0.045)$ & $(+)$ & Supported \\
\hline H7ISLAM & Extrinsic Religiousness $\rightarrow$ Pro-environmental identity & $0.071(0.022)$ & $(-)$ & Not Supported \\
\hline H8ISLAM & $\begin{array}{l}\text { Extrinsic Religiousness } \rightarrow \text { Attitudes towards } \\
\text { environmental issues }\end{array}$ & $-0.158 * *(0.021)$ & $(-)$ & Supported \\
\hline H9ISLAM & $\begin{array}{l}\text { Extrinsic Religiousness } \rightarrow \text { Subjective norms about the } \\
\text { environment }\end{array}$ & $-0.014(0.029)$ & $(-)$ & Not Supported \\
\hline
\end{tabular}

** $p<0.01 ; * p<0.05$ 
Table 6. Model estimates (CHRISTIANITY)

\begin{tabular}{|c|c|c|c|c|}
\hline & & $\begin{array}{c}\text { Standardized } \\
\text { parameter } \\
\text { estimates (Std. } \\
\text { Errors) } \\
\end{array}$ & $\begin{array}{l}\text { Hypothesized } \\
\text { Effects }\end{array}$ & $\begin{array}{l}\text { Hypothesis } \\
\text { Testing } \\
\text { Results }\end{array}$ \\
\hline H1CHRISTIANITY & Pro-environmental identity $\rightarrow$ Purchase Intention & $0.449 * *(0.073)$ & $(+)$ & Supported \\
\hline H2 CHRISTIANITY & $\begin{array}{l}\text { Attitudes towards environmental issues } \rightarrow \text { Purchase } \\
\text { Intention }\end{array}$ & $0.212 * *(0.083)$ & $(+)$ & Supported \\
\hline H3 ChRISTIANITY & $\begin{array}{l}\text { Subjective norms about the environment } \rightarrow \text { Purchase } \\
\text { Intention }\end{array}$ & $0.341 * *(0.048)$ & $(+)$ & Supported \\
\hline H4 CHRISTIANITY & Intrinsic Religiousness $\rightarrow$ Pro-environmental identity & $0.293 * *(0.048)$ & $(+)$ & Supported \\
\hline H5 CHRISTIANITY & $\begin{array}{l}\text { Intrinsic Religiousness } \rightarrow \text { Attitudes towards } \\
\text { environmental issues }\end{array}$ & $0.237 * *(0.040)$ & $(+)$ & Supported \\
\hline H6CHRISTIANITY & $\begin{array}{l}\text { Intrinsic Religiousness } \rightarrow \text { Subjective norms about the } \\
\text { environment }\end{array}$ & $0.315 * *(0.064)$ & $(+)$ & Supported \\
\hline H7CHRISTIANITY & Extrinsic Religiousness $\rightarrow$ Pro-environmental identity & $0.129 *(0.028)$ & $(-)$ & Not Supported \\
\hline H8CHRISTIANITY & $\begin{array}{l}\text { Extrinsic Religiousness } \rightarrow \text { Attitudes towards } \\
\text { environmental issues }\end{array}$ & $-0.077(0.025)$ & $(-)$ & Not Supported \\
\hline H9CHRISTIANITY & $\begin{array}{l}\text { Extrinsic Religiousness } \rightarrow \text { Subjective norms about the } \\
\text { environment }\end{array}$ & $0.042(0.039)$ & $(-)$ & Not Supported \\
\hline
\end{tabular}

$* * p<0.01 ;{ }^{*} p<0.05$ 